\title{
The Quality Effect of Service, Perception, Taxpayer Motivation of The Interest of Using Tax Consultant Services
}

\author{
Indra PAHALA ${ }^{*}$, Nuramalia HASANAH ${ }^{2}$, Rida KHAIRANI ${ }^{3}$, Kiswanto $^{4}$, Suherman ${ }^{5}$, \\ Ayatulloh Michael MUSYAFFI ${ }^{6}$
}

1,2,3,5,6Faculty of Economics, Universitas Negeri Jakarta, Indonesia, Jl Rawamangun Muka, Jakarta, Indonesia.

${ }^{4}$ Faculty of Economics, Universitas Negeri Semarang, Indonesia.

Email: indrapahala@unj.ac.id ${ }^{1}$, nuramalia@unj.ac.id², kiswanto@mail.unnes.ac.id ${ }^{3}$, kiswanto@mail.unnes.ac.id²,

Suherman@unj.ac.id ${ }^{5}$, musyaffi@unj.ac.id ${ }^{6}$

* Corresponding Author

Received: 10.09.2021 Accepted: 09.11.2021 Published: 03.12.2021 DOI: 10.47750/QAS/22.185.19

\begin{abstract}
The purpose of this study is to determine the effect of service quality, taxpayers' perceptions of tax consultants, and motivation of taxpayers to interest in using tax consultant services. The data analysis technique used in this research is descriptive statistics. The analytical method used in this research is multiple linear regression. There is a partially significant influence between service quality, perceptions of tax consultants, and motivation of taxpayers with interest in using tax consultant services, so it can be interpreted that if these three things the higher the taxpayers get, the higher the interest in using tax consulting services. This study assesses that the growth in the number of taxpayers in Indonesia should have an impact on economic growth in Indonesia, one of which comes from tax revenue. As part of the study, there are limitations of a person or agency in calculating taxes, of course, they need consultant services to help it all. The higher the use of tax consultant services, the higher the tax income for the state. This study considers indicators that are closely related to the internal and external conditions of taxpayers to find out what interests them in paying taxes through a tax consultant. Such an approach has several advantages over current methods: it is universal, indicators are available, and the calculations are clear.
\end{abstract}

Keywords: Service Quality, Taxpayer Perceptions, Taxpayer Motivation, Tax Consultant Services

\section{Introduction}

Human resources in Indonesia, which reaches 240 million people and are found throughout Indonesia, are quite difficult to set up development and equal distribution of people's welfare. The existence of many human resources, they are not necessarily successful in managing effectively and efficiently the wealth of natural resources. It takes great financial support in building infrastructure to maximize the management and processing of existing natural resources. Another consideration is that because Indonesia's natural resources will run out in the future, the state chooses taxes as the solution and the main priority in state revenue.

In the 2017 State Budget (APBN) posture, the amount of state revenue was set at IDR 1,750.3 trillion. This amount consists of tax revenues of IDR 1,489.9 trillion, non-tax state revenues (PNBP) of IDR 250 trillion, and grant revenues of IDR 1.4 trillion (Kemenkeu, 2017). Furthermore, in 2018, state revenue reached IDR 1,942.3 trillion or $102.5 \%$. This revenue was obtained from tax revenues of IDR 1,521.4 trillion, NonTax State Revenues (PNBP) of IDR 407.1 trillion, and grant revenues of IDR 13.9 trillion. The realization of tax revenue for 2018 amounted to IDR 1,315.9 trillion or grew by 14.3\%. According to the Minister of Finance (Kemenkeu), this tax growth was the highest since 2012. The tax ratio also reached $11.5 \%$ of the Gross Domestic Product (GDP), increasing by 0.8\% from 2017 (kemenkeu, 2018).

Tax, which is the main source of state revenue, must generate an even greater amount in the following years. This is because funding for the needs of the state will increase over time. To adjust the optimal tax revenue from the payable taxpayer, the government forms a tax consultant who can contribute to increasing taxpayer compliance. The existence of tax consulting services can help taxpayers to exercise their tax rights and obligations under tax laws.

Especially if there are taxpayers who are unfamiliar with taxes, plus there is a system called self-assessment system which requires taxpayers to calculate, pay, and report their tax obligations. On the other hand, taxpayers must do tax planning and management to minimize the amount of tax paid, besides that it does not rule out the possibility that human resources throughout the company can overcome tax problems faced by these companies, coupled with the complexity of taxation regulations in Indonesia, this is encouraging companies to make efforts to overcome taxation problems that occur, one of which is by using a tax consultant service (Munabari \& Aji, 2014).

One of the factors that cause taxpayers to be interested in using tax consultant services is the quality of services provided by the tax consultant. Taxpayers who use tax consultants or are called tax consultant clients sometimes do not always stay with the tax consultant for the next period. According to Clarissa and Mangoting in Indonesian context (Vanya, et al., 2013), this is because clients move to use other tax consultant services or taxpayers take care of their tax obligations because taxpayers already understand the field of 


\section{GENERAL MANAGEMENT}

taxation or have separate personnel to take care of their taxation sector. So, in this case, the quality of tax consultant services must meet certain criteria to attract taxpayers to use the tax consultant services.

The quality of tax consultant services affects the interest of taxpayers to use tax consultant services. This stated in Wijaya (2013) research, which reveals that the quality of tax consultant services affects corporate taxpayers using tax consultant services. Other research from Pontoh et al. (2017), that the quality factor of tax consultants has a significant partial and simultaneous effect on the interest of taxpayers to use tax consultant services.

Another factor that can affect the interest of taxpayers to use tax consulting services is the taxpayer's perception of tax consultants. Quoted in Supeno (2011), the perception of fit is high if there are similarities in perceptions between tax consultants and clients handled in the activities at hand (for example: consulting in the tax field) or image compatibility between tax consultants and clients (idiosyncratic theory concept) by the author (Gwinner, 1997), researchers (Badri \& Alfi, 2012), and high image.

Based on this background, the researcher is interested in conducting research related to the factors that affect the interest of individual taxpayers (service quality, taxpayer perceptions of tax consultants, and taxpayer motivation) in using tax consultant services.

\section{Literature Review}

A tax consultant is any person who, with his expertise and in his work environment, freely and professionally provides taxation services to clients in exercising their rights and fulfilling their tax obligations by applicable laws. Sutanto \& Tjondro. (2013), explains that tax consultants can carry out their duties professionally without being accused of being "naughty" tax consultants with five prerequisites, namely understanding taxation rules and other regulations, determining the purpose of tax planning, understanding business characteristics taxpayers, understand the level of fairness and know the field of accounting and business processes. Munabari and Aji (Munabari \& Aji, 2014) defines interest as a tendency and high enthusiasm or a great desire for something. According to Hartanto \& Tjondro (2013), this desire can be in the form of a taxpayer's desire to advance their business and manage finances through tax planning or the desire of taxpayers to get better services than those provided by tax officials.

In a service sales activity, for a company to be considered superior to other companies, quality service is required. According to Schiffman \& Kanuk (2004) in Suryani (2008) defines perception as an individual process in selecting, organizing, and interpreting a stimulus into something meaningful. As for Moscowitz and Ogel (1969) quoted in Munabari and Aji (Munabari \& Aji, 2014), it explains that perception is a process of organizing and interpreting the stimulus received by an organism or individual so that it becomes something meaningful and becomes an integrated activity in the individual.

In supporting an action or achievement, someone needs motivation. Motivation can be defined as an impulse in oneself to take an action consciously or unconsciously, this motivation can come from the needs and desires of everyone (Wijaya, 2013). According to Braithwaite, motivational posture is a social signal sent by individuals to tax collection authorities as a means of social communication to determine the social distance between taxpayers and tax collection authorities (Mangonting et al., 2013). From the explanation above, the researcher describes the research framework as follows:

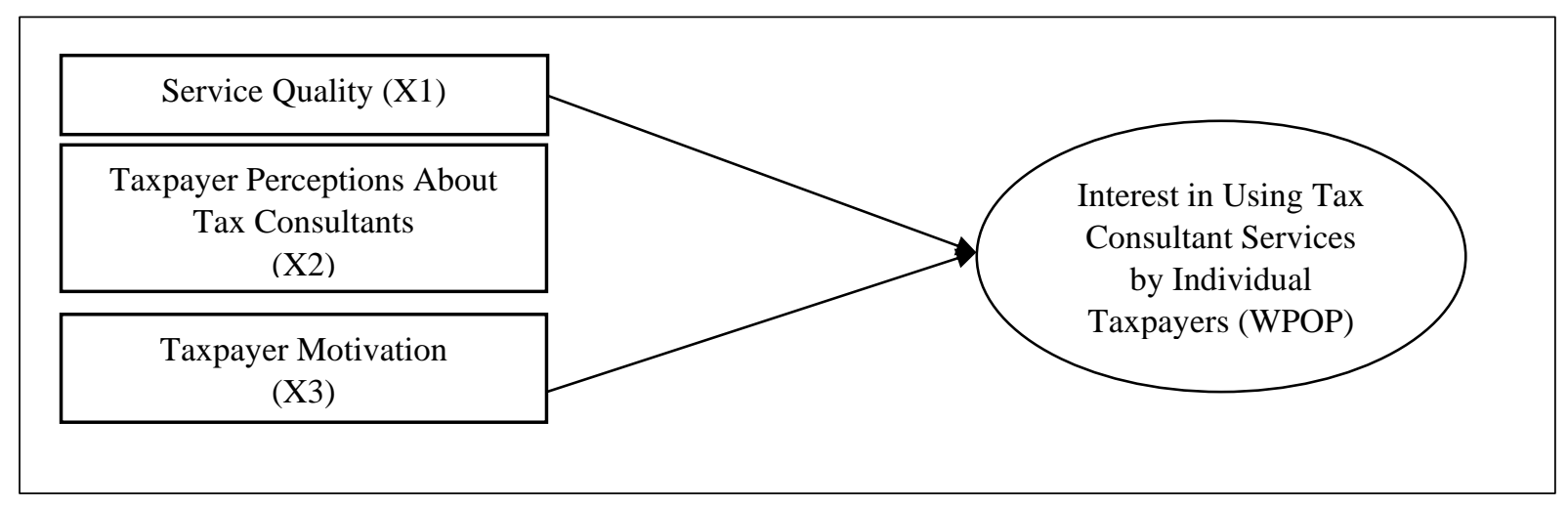

Figure 1: Research Framework

\section{Research Method}

The data used in this study are primary data obtained through a questionnaire as an instrument to examine the object of research. The object of this research is an individual taxpayer (WPOP) registered at the Pratama Tax Office (KPP), Duren Sawit, Jakarta. WPOP criteria are those who have business activities, both in the services, trading, manufacturing, and other sectors. The scope of this research is that which affects the interest of WPOP in using tax consultant services including service quality, perceptions of tax consultants, and taxpayer motivation.

The population used is WPOP, which has registered business activities at the Primary Tax Office, Duren Sawit, Jakarta. The number of WPOPs that have registered business activities at the Primary Tax Service Office, Duren Sawit,
Jakarta is 17743 (seventeen thousand seven hundred and forty-three) people. To determine the sample, in this study using probability sampling techniques with the sampling method, random sampling. With this sampling technique, it means that researchers provide equal opportunities to all elements of the population to be selected as samples.

The dependent variable of this research is Taxpayer's Interest in Using Tax Consultant Services ( $Y$ ). It is is a tendency or great desire of taxpayers to use tax consultant services who professionally provide tax services to clients or taxpayers. Then for the independent variable there are three variables among them Service Quality (X1), in Supeno (2011), service quality/service is a concept defined as the difference between the expectations for the desired service and the service received (client perception suitability). Perceptions About Tax Consultants (X2), it can be defined operationally as an ability to respond to or know about a tax consultant with the 
stimulus, namely the types of tax consultants which are then interpreted to be meaningful for taxpayers to determine their interest in using tax consultants' services. Taxpayer Motivation (X3), it is an encouragement to taxpayers to achieve certain goals. Motivation is formed when taxpayers feel that there is a need that must be met, namely, to use a tax consultant.

The data analysis technique used in this research is descriptive statistics. By using descriptive statistics, tests were carried out to determine the size of data concentration (mean) and the size of the data distribution (standard deviation, minimum, and maximum).

The method of analysis used in this research is multiple linear regression, to measure the effect of two or more independent variables on the dependent variable. In this study, using 3 (three) independent variables, namely service quality, perceptions of tax consultants, and mandatory motivation towards the interest of taxpayers to use tax consultant services which are the independent variables. The equation for multiple linear regression analysis used is as follows:

$$
\begin{aligned}
& Y=\alpha+\beta 1 . X 1+\beta 2 . X 2+\beta 3 . X 3+e \\
& \text { Information: } \\
& Y \quad: \text { Taxpayers' interest in using tax consultant services } \\
& X 1 \quad \text { : Quality of service }
\end{aligned}
$$

X2 : Perceptions about tax consultants

X3 : Taxpayer motivation

a : Constant

$\beta 1$ : Service quality regression coefficient

$\beta 2$ : Perception regression coefficient about tax consultants

\section{B3 : Taxpayer motivation regression coefficient}

e : Error

Furthermore, to test the quality of the model, the $F$ statistical test is used to test whether all independent variables can explain the dependent variable. The $\mathrm{F}$ test is also used to determine whether the model being tested is fit and feasible to continue. Besides, to test the hypothesis in this study using the t-test or partial effect test.

\section{Results and Discussion}

Based on the test with the multiple regression method that has been done, it proves that all the independent variables used in this study have a significant effect on the interest in using tax consulting services. The results of the t-test are shown in the following table:

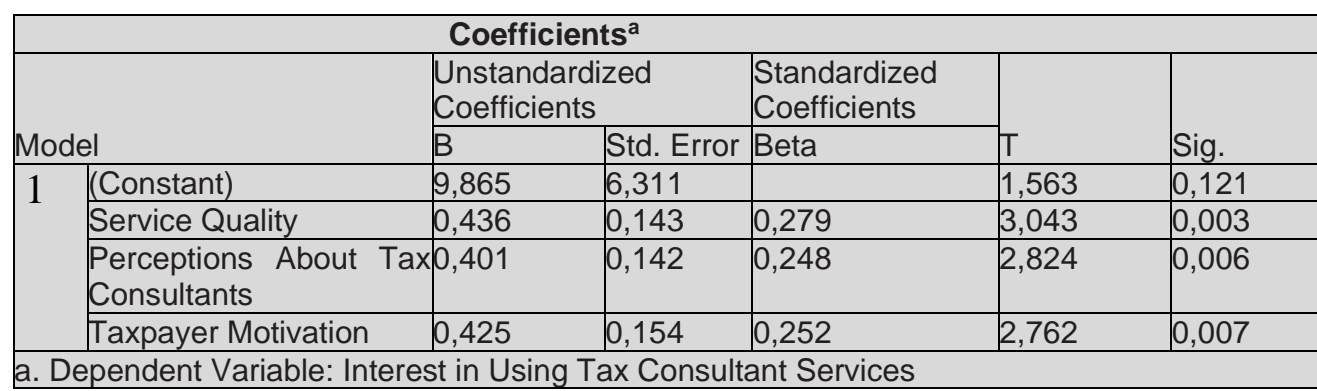

Table 1: T-Test

Based on the results of the t-test which can be seen in Table 1, the variable service quality has a significant effect on the interest in using tax consultant services. Service quality is the key to success in implementing tax consulting services which consist of the overall nature of the services provided. This is to attract customers or clients to use these products or services to achieve satisfaction, which in this study refers to services provided by tax consultants.

The results of this study are in line with the research of Pontoh et al. (2017) which states that partially testing the quality of tax consultants has a significant effect on the use of tax consultant services based on the t-count value for the taxpayer motivation variable $\left(X_{1}\right) 2.916$ greater than the t-table value of 1.660 with a significance level of $0.004<0.05$. Besides, this study is also consistent with the research of Clarissa and Mangoting (Vanya, et al., 2013) which states that the quality of tax consultant services has a significant effect on client satisfaction with tax consultant services. Tax consultants are expected to provide services that can meet and answer the needs and problems of clients at anytime, anywhere, and under any conditions quickly and precisely. Taxpayers believe this because tax consultants are considered capable of handling the tax problems, they experience with proper handling to increase the value of service quality which results in increased interest in taxpayers to use tax consultant services.

By the results of data processing, it proves that the perception of tax consultants has a significant effect on the interest in using tax consultant services. There are 3 types of combined tax consultants, including Honest and Cautious Consultant, Creative and Cautious Consultant, and Honest, Creative, and Cautious Consultant. With the 3 combined types of tax consultants, taxpayers have their perceptions of their interest in using tax consultant services. Taxpayers will later find an option, namely whether the taxpayer in carrying out tax obligations will follow the applicable regulations with a straight tax consultant or take other ways of carrying out tax obligations with a tax consultant who can be worked with.

Perception variable about tax consultant as an ability in responding or knowing about tax consultant with the stimulus, namely the types of tax consultants which are then interpreted into something meaningful for taxpayers to determine their interest in using tax consultant services. The types of tax consultants that are by the criteria of taxpayers will affect the interest of taxpayers to use tax consultant services.

The results of the study are consistent with previous research, namely research by Sutanto \& Tjondro (2013) which states that there is a correlation between the perceptions and preferences of taxpayers in using tax consultant services. The relationship between perceptions and preferences for tax consultants means that taxpayers choose a tax consultant based on the suitability and desirability of different perceptions of each taxpayer regarding the tax consultant (types of tax consultants). If the perception matches his preference for tax consultants, it will increase the interest of the taxpayer to use tax consultant services. So, it can be concluded that the perception of taxpayers (regarding the types of tax consultants) has a significant effect on the interest of taxpayers to use tax consultant services.

Based on the results of the t-test which can be seen in Table 1, the taxpayer motivation variable has a significant effect on the interest in using tax consultant services. This means that the higher the motivation obtained by the taxpayer, the higher the taxpayer's interest will be in using the tax 


\section{GENERAL MANAGEMENT}

consultant's services. Taxpayer motivation can be measured by how much the taxpayer wants to use the services of a tax consultant without violating tax laws (Pontoh et al., 2017).

Taxpayer motivation in this study includes intrinsic, extrinsic, and urgent motivation. Extrinsic motivation arises when there are suggestions from other parties regarding the use of tax consultant services, such as from family or closest colleagues as well as from advertising media and so on. Meanwhile, urgent motivation arises when taxpayers are required to appoint a tax consultant as a tax representative/proxy and to obtain the title of an obedient taxpayer.

The results of this study are in line with research conducted by Pontoh et al. (2017) which revealed that taxpayer motivation has a partially significant effect on the use of tax consultant services. The t-value for the taxpayer motivation variable $\left(X_{1}\right) 7,716$ is greater than the t-table value of 1,660 with a significance level of $0,000<0.05$. So, it can be said that the higher the motivation of the taxpayer, the higher the interest in using tax consulting services.

\section{Conclusion and Implications}

Based on the research results, the conclusions in this study are as follows (1) There is a partially significant influence between service quality and interest in using tax consultant

\section{References}

[1] Badri \& Alfi. (2012). Impact of Brand Conformity/Cause and Individualism-Collectivism on Consumer Intention to Participate in CRM Programs. Airlangga University

[2] Crookes, G., \& Schmidt, R. W. (1991). Motivation: Reopening the Research Agenda. Language Learning, 41(4), 469-512. doi:10.1111/j.1467-1770.1991.tb00690.x

[3] Elliot, A. J., \& Covington, M. V. (2001). Educational Psychology Review, 13(2), 73-92. doi:10.1023/a:1009009018235

[4] Febe, A. Wijaya. (2013). Analysis of Factors Affecting Corporate Taxpayers Using Tax Consultant Services. Universitas Kristen Petra Surabaya

[5] Gwinner, K. (1997). A model of image creation and image transfer in event sponsorship. International Marketing Review, 14(3), 145-158. doi:10.1108/02651339710170221

[6] Hartanto \& Tjondro. (2013). Influence of Taxpayer Perception on Tax Knowledge, Super Ego Motives, Service of Tax Officials and Role as Taxpayer's Representative on Individual Taxpayer's Request for Tax Consultant Services in KPP Mulyorejo Area Surabaya. 3(2).

[7] https://www.kemenkeu.go.id/apbn2017

[8] https://www.kemenkeu.go.id/publikasi/berita/ini-capaianapbn-2018/

[9] Hutagaol. (2006). Capita Selecta Tax. Jakarta: Salemba Empat

[10] Kristanto, P. (2009). Become a World Class Tax Consultant. PT. Elex Media Komputindo: Jakarta.

[11] Lehtinen, U. \& Lehtinen, J.R. (1982). A Study of Quality Dimensions. Service Management Institute, 5, 25-32. Scientific Research.

[12] Mangonting, Yenni \& Sadijarto A. (2013). The effect of motivational posture on individual taxpayer compliance. Journal of the Faculty of Economics, Indonesian Computer University.

[13] Moskowitz, Marley JN' Arthur Ogel. (1969). General Psychology. New York: Houghton Mufflen. services, so it can be interpreted that if the better the quality of service, the more interest in using tax consultant services wil increase. (2) There is a partially significant influence between perceptions of tax consultants and interest in using tax consultant services so that it means that the better the perception of tax consultants, the higher the interest in using tax consultant services. (3) Then there is a partially significant influence between taxpayer motivation and interest in using tax consultant services so that the meaning is that if the higher motivation is obtained by the taxpayer, the higher the interest in using tax consultant services.

This research also provides several implications, it is (1) The quality of service in this research is very important, such as the problem handling factor (service recovery) if there is an error or something unexpected happens, the respondent wants the tax consultant to immediately take action to control the situation and find the right solution to the problem. This is the main factor for taxpayers in their interest in using tax consultant services. (2) Taxpayers 'perceptions of tax consultants, namely the types of tax consultants that are by the criteria of taxpayers are very important considering that the taxpayers' objectives are adjusted in using tax consultant services. So that taxpayers can determine their preferences (preferences) what type of tax consultant is in the context of using tax consultant services.

[14] Munabari \& Aji. (2014). Analysis of the Effect of Tax Knowledge, Perceptions of Tax Consultants, and Perceptions of Account Representatives on Interest in Using Tax Consultant Services for Corporate Taxpayers at KPP Pratama Bantul. Jurnal Akuntansi, 2(2) ://jurnalfe.ustjogia.ac.id/index.php/akuntansi/article/view/36

[15] Poerwadarminta. W.J.S. (2003). General Indonesian Dictionary. Jakarta : Balai Pustaka

[16] Pontoh, Elim, \& Budiarso. (2017). Analysis of Factors Affecting Taxpayers Using Tax Consultant Services. ISSN 2303-1174.

https://ejournal.unsrat.ac.id/index.php/emba/article/view/161 25

[17] Sasser, W. E., Olsen, R. P. \& Wyckoff, D. D. (1978). Management of Service Operations. Boston: Allyn \& Bacon.

[18] Schiffman, L. G. \& Kanuk, L. L. (2004). Consumer behavior, 8th International edition. Prentice Hall.

[19] Supeno, H. (2011). The Influence of Management Participation on Compliance, Report Truth, Transparency, and Accountability Through Institutional Accounting (Studies on State Higher Education Agencies and East Java Regional Government Institutions/Units) Faculty of Economics, University of 45, Surabaya. Economic Magazine. Year XXI, No. August 2, $2011.2 \mathrm{https}: / / \mathrm{e}$ journal.unair.ac.id/JEBA/article/view/4296/2934

[20] Sutanto \& Tjondro. (2013). Taxpayer Perception of Tax Consultant and Taxpayer Preference in Choosing Tax Consultant: Honest Consultant, Creative Consultant, and Cautious Consultant. Tax \& Accounting Review, 3(2), http://publication.petra.ac.id/index.php/akuntansipajak/article/view/3068

[21] Suryani, T. (2008). Consumer Behavior Implications for Marketing Strategy. Yogyakarta: Graha IImu

[22] The Indonesian tax director general. (2020).

[23] Vanya, Clarissa. \& Yenni Mangoting. (2013). Pengaruh Kualitas Jasa Konsultan Pajak Terhadap Kepuasan Klien di Surabaya 